\title{
ANKSIOZNOST PACIJENATA KOD PREGLEDA VIŠESLOJNOM KOMPJUTORIZIRANOM TOMOGRAFIJOM U ŽUPANIJSKOJ BOLNICI LIVNO
}

\author{
Stipe Badrov ${ }^{1}$, Dragan Babić ${ }^{1,2}$, Darjan Franjić, ${ }^{1,3}$, Marko Martinac ${ }^{2}$, Miro Miljko \\ ${ }^{1}$ Fakultet zdravstvenih studija Sveučilišta u Mostaru \\ ${ }^{2}$ Klinika za psihijatriju, Sveučilišna klinička bolnica Mostar \\ ${ }^{3}$ Klinika za Onkologiju, Sveučilišna klinička bolnica Mostar \\ 88000 Mostar, Bosna i Hercegovina
}

Rad je primljen 29.08.2020.. Rad je recenziran 26.010.2020. Rad je prihvaćen 27.10.2020.

\section{SAŽETAK}

UVOD: Pregled višeslojnom kompjutoriziranom tomografijom (engl. MSCT - Multislice Computed Tomography) je bezbolan, ali može biti stresan za pacijenta i izazvati anksioznost.

CILJ: Utvrditi pojavnost anksioznosti pacijenata prije i poslije pregleda višeslojnom kompjutoriziranom tomografijom.

METODE: U studiju su uključeni pacijenti kojima je potreban pregled MSCT-om u Županijskoj bolnici u Livnu. Ispitnu skupinu ( $\mathrm{N}=50)$ predstavljaju ispitanici kojima je ordiniran MSCT pregled. Kontrolnu skupinu (N=50) predstavljaju ispitanici kojima je ordiniran rendgenski pregled. Primijenjen je upitnik sociodemografskih podataka i upitnik za samoprocjenu anksioznosti (STAI).

REZULTATI: Razina anksioznosti kao stanja ličnosti je statistički značajno viša u kontrolnoj skupini. U odnosu na anksioznost kao osobine ličnosti u istraživanom uzorku nije bilo statistički značajnih razlika u rezultatima među skupinama. Ispitanici s nižim stupnjem naobrazbe i koji nisu pili alkoholna pića postizali su statistički značajno više rezultate na upitniku za procjenu anksioznosti kao osobine ličnosti.

ZAKLJUČAK: Statistički značajno je veća prisutnost anksioznosti pacijenata prije pregleda, nego poslije pregleda. Razina anksioznosti kao stanja ličnosti u ispitanika pokazala se statistički značajno manja u odnosu na anksioznost kao osobine ličnosti.

Ključne riječi: anksioznost, pacijenti, pregled, višeslojna kompjuterizirana tomografija

Kontakt osoba:

Prof. dr. sc. Dragan Babić

E-mail: dragan.babic@fzs.sum.ba 


\section{UVOD}

Anksioznost je specifično stanje subjektivnog osjećaja neugode i straha. U današnje vrijeme anksioznost je prisutna u određenoj fazi života kod gotovo svakog čovjeka, što ne znači da svi imaju anksiozni poremećaj (1). To je stanje napetosti, zabrinutosti, očekivanja da će se nešto strašno dogoditi. Predstavlja neugodno proživljavanje u kojem čovjek nije svjestan ni izvora ni objekta svoga straha, i predstavlja anticipaciju nesnosnog stanja preplavljenosti vanjskim i unutrašnjim silama (2). Anksiozni poremećaji uzrok imaju pretežito u psihološkim čimbenicima, premda postoje dokazi i o genetskom utjecaju i neurofiziološkoj podlozi. Neurotična anksioznost je slična strahu, ali se javlja kada nema vidljive opasnosti, kroz opću zabrinutost, predosjećaj opasnosti (3). Pacijent koji dolazi na radiološku dijagnostiku, uglavnom dolazi u nepoznato okruženje (1). Ova spoznaja te strah od dijagnoze su čimbenici koji utječu na pojavu anksioznosti u pacijenata kojima je ordiniran radiološki pregled. Pojedini autori ističu da ozbiljna anksioznost može uzrokovati pomicanje pacijenta tijekom pregleda, što dovodi do lošije dijagnostičke slike i smanjenja kvalitete dijagnostičke pretrage (4). Svaki pacijent tijekom iščekivanja radiološke pretrage može osjetiti stupanj anksioznosti (5). Višeslojna kompjutorizirana tomografija (engl. MSCT - Multislice Computed Tomography) dijagnostička je metoda tijekom koje se snimani dio tijela izlaže rendgenskom zračenju što omogućuje detaljan anatomski prikaz kosti, mekih tkiva i krvnih žila. U pojedinim slučajevima indicirana je primjena kontrastnog sredstva peroralnim putem ili intravenski. Aplikacija kontrastnog sredstva ponekad može izazvati određene komplikacije kao što je alergijska reakcija (6). Dijagnostički pregled MSCT-om je bezbolan, ali ipak može biti stresan za pacijenta te kod istih može izazvati anksioznost (7). Tijekom pregleda MSCT-om, gubitak kontrole predstavlja dodatni čimbenik koji značajno pridonosi osjećaju anksioznosti (8). Osim toga, strah od boli i nepoznatog isto tako mogu utjecati na povećanje anksioznosti, izazivajući napad klaustrofobije zbog otvora kroz koji pacijent mora proći tijekom MSCT pregleda (9). Opis anksioznosti je nejasan, trajanje je dugo i obično kronično (10). Pored toga, anksioznost može biti i kao oblik stanja. Anksiozne osobe su svjesne nerealnosti i nelogičnosti straha, ali nisu u stanju naći prikladna objašnjenja za njegov nastanak niti se suočiti sa njima zastrašujućim situacijama i objektima (11). Pregled MSCT-om i ostalim radiološkim pretragama za većinu ljudi je neugodan. Zbog toga je veća vjerojatnost pojave anksioznosti kod pacijenata kojima je ordinirana pretraga, nego kod onih koji nemaju zakazan termin za pregled (12).

Cilj ovog istraživanja bio je utvrditi pojavnost anksioznosti pacijenata prije i poslije pregleda višeslojnom kompjutoriziranom tomografijom.

\section{ISPITANICI I METODE}

\section{Ispitanici}

Ispitivanje je obuhvatilo studiju gdje su bili uključeni svi pacijenti kojima je potreban pregled MSCT-om u županijskoj bolnici u Livnu. Uključeno je 100 ispitanika. Ispitanici su podijeljeni u dvije skupine. Ispitnu skupinu $(\mathrm{N}=50)$ predstavljali su ispitanici koji se nalaze na pregledu MSCT-om. Kontrolnu skupinu $(\mathrm{N}=50)$ predstavljali su ispitanici koji se nalaze na pregledu rendgenom. Ispitanicima je na dan njihovih pristupanja pregledu ponuđen prvi dio upitnika, kojim se mjeri trenutno stanje koji su trebali popuniti. Prije same primjene upitnika pacijentima je naglašeno kako je istraživanje u potpunosti anonimno i kako će se podatci koristiti isključivo za potrebe izrade diplomskog rada te je sve u skladu sa etičkim načelima. Zamoljeni su za potpunu suradnju. Rečeno im je da tvrdnje predstavljaju opis nekih uobičajenih reakcija, stavova, ponašanja i doživljavanja ljudi, te da izraze svoj stupanj slaganja sa svakom od tvrdnji. Ispitivanje je u prosjeku trajalo između 15 i 20 minuta. Svaki je upitnik imao zasebnu uputu.

Nakon popunjavanja upitnika, sa svakim ispitanikom zasebno, dogovoren je ponovni susret nakon 24 sata odnosno po preuzimanju nalaza, u svrhu popunjavanja drugog dijela upitnika.

\section{Metode}

Istraživački instrument predstavljale su dvije vrste upitnika: upitnik općih sociodemografskih podataka i upitnik za samoprocjenu anksioznosti STAI (engl. StateTrait Anxiety Inventory) (13). Sociode- 
Badrov S, Babić D, Franjić D, Martinac M, Miljko M. Anksioznost pacijenata kod pregleda višeslojnom kompjutoriziranom tomografijom u Županijskoj bolnici Livno. Zdravstveni glasnik. 2020;6(2):13-22.

mografski upitnik je osobne izrade, namjenski sačinjen za ovo istraživanje. Sastoji se od podataka za spol, dob, mjesto stanovanja, pušenje, pijenje alkoholnih pića, obrazovanje, religioznost, radni odnos, bračni status. Upitnik anksioznosti kao stanja i osobine ličnosti konstruiran je na temelju Spielbergerovih postavki o razlikovanju anksioznosti kao stanja i kao osobine ličnosti. Sastoji se od dviju odvojenih ljestvica za samoprocjenu, namijenjenih utvrđivanju anksioznosti kao stanja i osobine. Ljestvica stanja anksioznosti (Oblik 1- M) sadrži 20 tvrdnji kojima se procjenjuje kako se ispitanik osjeća sada, u ovom trenutku. Ljestvica anksioznosti kao osobine (Oblik 2-M ) ima 20 tvrdnji kojima se mjeri kako se ispitanik općenito osjeća. Ispitanikov je zadatak da uz svaku tvrdnju zaokruži jedan odgovor na skali od 4 stupnja koji najbolje opisuje stupanj njegovog trenutačnog ili općenitog stanja (1-uopće ne, 2-malo, 3 -umjereno i 4-jako). Upitnik je namijenjen pojedinačnoj i skupnoj primjeni, a ispunjavanje upitnika nije vremenski ograničeno. Ukupan rezultat se dobiva tako da se zbroje bodovi za svih 20 tvrdnji za svaku ljestvicu pojedinačno. Najmanji mogući rezultat je 20, a najveći mogući 80 . Tijekom standardizacije Oblika 2 uvijek je prvo primjenjivana 1-M, a potom 2-M ljestvica; te je taj redoslijed preporučljiv uvijek kada se primjenjuju obje ljestvice. Budući da je 1-M ljestvica konstruirana tako da bude osjetljiva na uvjete u kojima se primjenjuje, na dobivene rezultate može utjecati ozračje koje bi nastalo ako se prvo primjeni 2-M ljestvica. Nasuprot tome, pokazalo se da je 2-M ljestvica razmjerno neosjetljiva na uvjete primjene. Ljestvicom stanja anksioznosti procjenjuju se bitna obilježja tog stanja: strepnja, napetost, nervoza i zabrinutost. Osim za utvrđivanje kako se ljudi osjećaju upravo sada, može se upotrijebiti i za procjenu nečijeg stanja anksioznosti u različitim zamišljenim situacijama, situacijama iz prošlosti ili budućnosti. Utvrđeno je i da je 1-M ljestvica osjetljiv pokazatelj prolazne anksioznosti koju klijenti doživljavaju u savjetovališnom radu, psihoterapiji, ali i kao pokazatelj razine anksioznosti pri suočavanju s neizbježivim stresorima iz svakodnevnog života. Ljestvica anksioznosti kao osobine često je primjenjivana u procjeni kliničke anksioznosti ljudi s tjelesnim, psihofizičkim i psihijatrijskim obo- ljenjima, ali i procjeni anksioznosti srednjoškolaca, studenata i sl. U kliničkim i eksperimentalnim istraživanjima pokazala se korisnom u otkrivanju povišene razine neurotske anksioznosti (14). Stabilnost, određena koeficijentima test-retest pouzdanosti, razmjerno je visoka za 2-M ljestvicu (oko 0.76), a niska za 1-M ljestvicu (oko 0.33), što se moglo i očekivati jer je riječ o instrumentu koji mjeri promjene u anksioznosti u različitim situacijama. Unutrašnja dosljednost, utvrđena Cronbachovim alfa koeficijentima, je s druge strane vrlo visoka (oko 0.90). Dobra konstruktna i dijagnostička valjanost vidljive su iz podataka da se ovim upitnikom razlikuju normalni ljudi i psihijatrijski bolesnici kojima je glavni simptom anksioznost, te rezultati normalnih ispitanika prije i nakon nekih stresnih situacija; iz podataka o povezanosti 1-M i 2-M ljestvica (0.65); iz podataka o povezanosti rezultata $\mathrm{O}$-ljestvice s drugim mjerama anksioznosti kao osobine (0.41-0.85); te s drugim upitnicima ličnosti i testovima obrazovnih sposobnosti i testovima postignuća (15).

\section{Statistička obrada podataka}

Dobiveni rezultati su obrađeni pomoću deskriptivnih te neparametrijskih i parametrijskih statističkih metoda ovisno o distribuciji podataka. Neparametrijske varijable su prikazane kao frekvencija i postotak, a parametrijske varijable, ovisno o distribuciji, su prikazane kao aritmetička sredina i standardna devijacija ili kao medijani interkvartalni raspon. Za testiranje razlike među skupinama korišten je hi-kvadrat test za nominalne varijable. Za testiranje razlike među ispitivanim skupinama, ovisno o normalnosti raspodjele kontinuiranih varijabli, korišten je Student t-test ili Mann-Whitney U test. Razina vjerojatnosti $\mathrm{p}<0,05$ smatrana je statistički značajnom. Statistička analiza obavljena je pomoću programskih sustava SPSS (engl. Statistical Package for the Social Sciences) za Windows (inačica 17.0, SPSS Inc, Chicago, Illinois,SAD) i Microsoft Excel (inačica 12.0, Microsoft Corporation, Redmond, WA, SAD).

\section{REZULTATI}

Obrađeni su rezultati 100 ispitanika. Muških ispitanika bilo je 43, dok je ženskih bilo 57 . Njih 83 
Badrov S, Babić D, Franjić D, Martinac M, Miljko M. Anksioznost pacijenata kod pregleda višeslojnom kompjutoriziranom tomografijom u Županijskoj bolnici Livno. Zdravstveni glasnik. 2020;6(2):13-22.

je nastanjeno u Livnu, 14 u Glamoču te 3 ispitanika su bila iz Tomislavgrada. Od ukupnog broja ispitanika 19 ima nižu stručnu spremu (NSS), 49 srednju stručnu spremu (SSS) dok je 32 ispitanika imalo višu stručnu spremu (VSS). Pedeset ispitanika je bilo u radnom odnosu dok 44 ispitanika nisu u radnom odnosu. Šest ispitanika je povremeno zaposleno. Ukupan broj religioznih ispitanika iznosio je 96 dok su se četiri ispitanika izjasnila kao nereligiozni. Struktura uzorka po bračnom statusu je iznosila: u braku 60, nije u braku 30, te 10 udovac/ica. Od ukupnog broja ispitanika 61 pije alkoholna pića dok ih 39 ne pije alkoholna pića te 80 ispitanika ne puši cigarete dok ih 20 puši cigarete. Skupina kojoj je rađen MSCT sadržavala je značajno veći postotak pušača $(\chi 2=7,563 ; p=0,006) . \mathrm{U}$ ostalim varijablama nije bilo statistički značajnih razlika među skupinama. U istraživanom uzorku nije bilo statistički značajnih razlika u dobi među skupinama.

Razlike u uzorcima skupina kojima je ordinirana MSCT odnosno RTG pretraga u odnosu na anksioznost kao stanje ličnosti postoje. Razliku prikazuje grafikon koji prikazuje usporedna očitovanja ispitanika obje skupine na zadane tvrdnje iz upitnika za samoprocjenu anksioznosti kao stanja ličnosti STAT-1. Srednja vrijednost za skupinu kojoj je ordiniran MSCT pregled iznosi 50286, a za skupinu kojoj je ordiniran RTG pregled srednja vrijednost iznosi 52,082 ( $\mathrm{t}=0,809 ; \mathrm{p}=0.419)$. Premda razlika nije statistički značajna, vidljivo je da skupina kojoj je ordiniran RTG pregled pokazuje višu razinu anksioznosti kao stanja ličnosti (Slika 1).

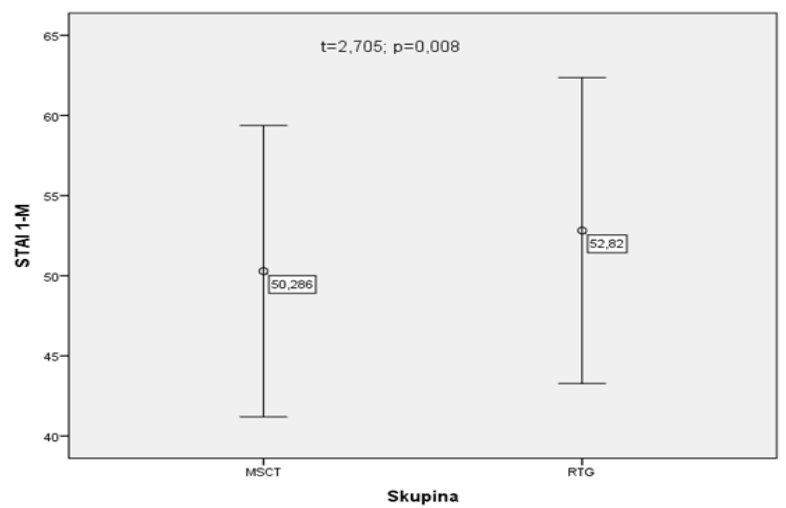

Slika 1. Razlike u rezultatima na STAI 1-M upitniku među skupinama.
Razlike u uzorcima dviju skupina u rezultatima dobivenih upitnikom za samoprocjenu anksioznosti kao osobine ličnosti STAI 2-M postoje. Srednja vrijednost za skupinu kojoj je ordiniran MSCT pregled iznosi 52, a za skupinu kojoj je ordiniran RTG pregled srednja vrijednost iznosi 51,531 ( $\mathrm{t}=0,521$; $\mathrm{p}=0,604)$. Iako $\mathrm{u}$ istraživanom uzorku nije bilo statistički značajnih razlika u rezultatima na STAI 2-M upitniku među skupinama, iz dobivenih rezultata je vidljivo da je skupina kojoj je ordiniran MSCT pregled iskazala višu razinu anksioznosti kao osobine ličnosti u odnosu na skupinu kojoj je ordiniran RTG pregled.

Za muški spol u testu STAI 1-M aritmetička sredina je iznosila 51,45 dok je standardna devijacija iznosila 4,830. U testu STAI 2-M aritmetička sredina za muški spol je iznosila 50,98 dok je prosječno odstupanje od prosječne vrijednosti bilo 4,114. U testu STAI 1-M aritmetička sredina za ženski spol je iznosila 51,65 dok je prosječno odstupanje od prosječne vrijednosti bilo 4,835. U testu STAI 2-M aritmetička sredina je iznosila 52,38 dok je standardna devijacija iznosila 4,661. Navedeni rezultati pokazuju da nije bilo statistički značajnih razlika među spolovima $\mathrm{u}$ rezultatima na testovima anksioznosti STAI 1-M $(\mathrm{t}=0,200 ; \mathrm{p}=0,842)$ i STAI 2-M $(\mathrm{t}=1,556 ; \mathrm{p}=0,123)$.

Srednja vrijednost $\mathrm{u}$ rezultatima na upitniku za samoprocjenu anksioznosti kao stanja ličnosti za skupinu koja se izjasnila da ima NSS stupanj edukacije iznosi 52, a srednja vrijednost i za skupinu koja se izjasnila da ima SSS i za skupinu koja se izjasnila da ima VSS stupanj edukacije iznosi 51. Iz navedenih rezultata vidljivo je da $\mathrm{u}$ istraživanom uzorku nije bilo statistički značajnih razlika u rezultatima na STAI 1-M upitniku među skupinama u odnosu na stupanj edukacije ( $\chi 2=3,191 ; \mathrm{df}=2 ; \mathrm{p}=0,203)$. Srednja vrijednost u rezultatima na upitniku za samoprocjenu anksioznosti kao osobine ličnosti za skupinu koja se izjasnila da ima NSS stupanj edukacije iznosi 54, za skupinu koja se izjasnila da ima SSS iznosi 52 dok za skupinu koja se izjasnila da ima VSS stupanj edukacije iznosi 50. Iz rezultata je vidljivo da su ispitanici s NSS stupnjem naobrazbe postizali statistički značajno najviše rezultate na STAI 2-M $(\chi 2=8,299 ; \mathrm{df}=2 ; \mathrm{p}=0,016)$ (Slika 2). 
Badrov S, Babić D, Franjić D, Martinac M, Miljko M. Anksioznost pacijenata kod pregleda višeslojnom kompjutoriziranom tomografijom u Županijskoj bolnici Livno. Zdravstveni glasnik. 2020;6(2):13-22.

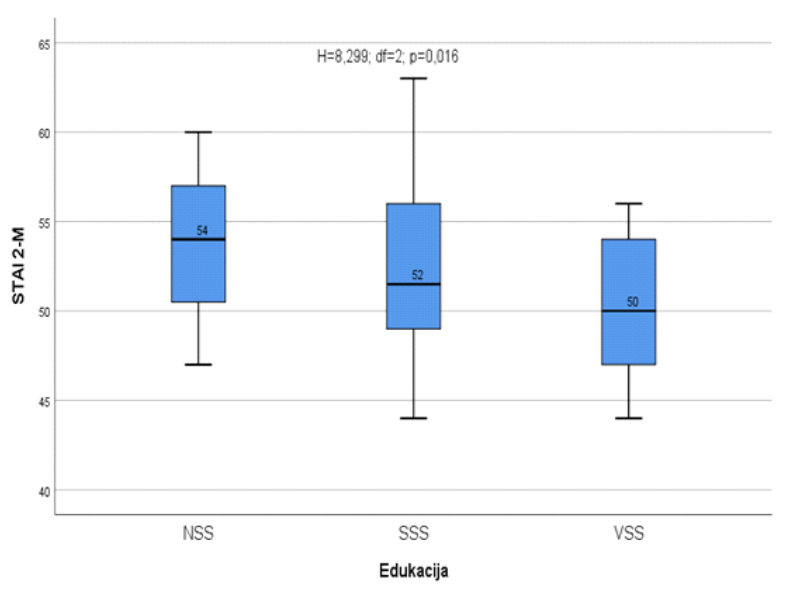

Slika 2. Razlike u rezultatima na STAI 2-M upitniku u odnosu na stupanj edukacije

Ispitanici koji nisu pili alkoholna pića su postizali značajno više rezultate na STAI 2-M upitniku kojim se analizirala prisutnost anksioznosti kao osobine ličnosti (Tablica 1).

Tablica 1. Razlike u rezultatima na skalama anksioznosti u odnosu na pijenje alkoholnih pića.

\begin{tabular}{llllllll}
\hline & \multicolumn{4}{l}{ Alkohol } & & \\
\cline { 2 - 5 } & $\mathrm{Da}$ & \multicolumn{3}{l}{$\mathrm{Ne}$} & & $\mathrm{t}^{\dagger}$ & $\mathrm{P}^{\dagger \dagger}$ \\
\cline { 2 - 5 } & $\overline{\mathrm{X}}^{*}$ & $\mathrm{SD}^{* *}$ & $\overline{\mathrm{X}}$ & $\mathrm{SD}$ & & \\
\hline STAI 1-M & 50,61 & 4,565 & 52,16 & 4,896 & 1,580 & 0,117 \\
STAI 2-M & 50,58 & 4,157 & 52,51 & 4,523 & 2,128 & 0,036 \\
\hline
\end{tabular}

${ }^{*}$ Aritmetička sredina; ${ }^{*}$ Standardna devijacija; $\uparrow$ Studentov t-test; $\uparrow \dagger p<0,05$

U Tablici 2 vidljivo je da nije bilo statistički značajnih razlika na skalama anksioznosti u odnosu na pušenje.

Tablica 2. Razlike u rezultatima na skalama anksioznosti u odnosu na pušenje.

\begin{tabular}{llllllll}
\hline & \multicolumn{4}{l}{ Cigarete } & & \\
\cline { 2 - 5 } & $\mathrm{Da}$ & \multicolumn{3}{l}{$\mathrm{Ne}$} & & $\mathrm{t}^{\dagger}$ & $\mathrm{P}^{\dagger \dagger}$ \\
\cline { 2 - 5 } & $\overline{\mathrm{X}}^{*}$ & $\mathrm{SD}^{* *}$ & $\overline{\mathrm{X}}$ & $\mathrm{SD}$ & & \\
\hline STAI 1-M & 51,35 & 6,418 & 51,62 & 4,360 & 0,223 & 0,824 \\
STAI 2-M & 50,95 & 3,456 & 51,97 & 4,682 & 1,096 & 0,280 \\
\hline
\end{tabular}

${ }^{*}$ Aritmetička sredina; ${ }^{*}$ Standardna devijacija; $†$ Studentov $\mathrm{t}$-test; $\dagger \dagger \mathrm{p}<0,05$

\section{RASPRAVA}

Rezultati našeg istraživanja pokazuju da je skupina ispitanika kojima je ordiniran RTG pregled anksioznija u trenutku ispitivanja od ispitanika kojima je ordiniran MSCT pregled. U odnosu na opću anksioznost razlika između dviju skupina nije statistički značajna, iako su ispitanici koji su ordinirani na pregled MSCT-om pokazali višu razinu opće anksioznosti. Na temu analize anksioznosti kod različitih radioloških pregleda provedena su brojna istraživanja, a najviše njih se bavilo anksioznošću kod pregleda magnetskom rezonancom (engl. MRI - Magnetic Resonance Imaging). Naime, i MSCT i MRI se sastoje od gentrija, odnosno otvora u koji ulazi pacijent tijekom snimanja. Kod MRI uređaja taj otvor je uži, stoga kod pacijenata sklonih klaustrofobiji češće izaziva strah što je jedan od razloga zašto je anksioznost češće istraživana u pacijenata kojima je ordiniran MRI pregled. Nadalje, razlika je i u trajanju pretrage s obzirom da MRI traje duže od MSCT pregleda što može utjecati na višu razinu anksioznosti između ove dvije pretrage. Kod MSCT pregleda određenu komplikaciju može predstavljati i kontrast koji može izazvati alergijsku reakciju što se češće događa prilikom MSCT pregleda nego pri izvođenju MRI pretrage (16). Lo Re i sur. su 2016. godine proveli istraživanje čiji rezultati pokazuju da je $91 \%$ ispitanika imalo određenu razinu anksioznosti neovisno o vrsti radiološkog pregleda (17). Najviša razina anksioznosti pronađena je $u$ ispitanika kojima je ordiniran MRI pregled. Flory i Lang su 2011. godine objavili rad koji se bavio razinom stresa u pacijenata koji čekaju određeni radiološki dijagnostički pregled (18). Za razliku od našeg rada, autori navedenog rada su imali dvije kontrolne skupine koje su predstavljali pacijenti koji su čekali na biopsiju dojke i na transarterijsku kemoembolizaciju. Rezultati njihovog rada pokazuju da je zabilježena veća doza stresa kod pacijenata koji čekaju na radiološki pregled u čekaonici nego kod pacijenata koji su čekali na invazivnije i bolnije preglede. Takve rezultate autori opravdavaju iščekivanjem rezultata pretraga i bojaznošću od moguće nepovoljne dijagnoze za pacijenta. Rezultati Flory i Langa se podudaraju s rezultatima ovog rada koji također pokazuju 
Badrov S, Babić D, Franjić D, Martinac M, Miljko M. Anksioznost pacijenata kod pregleda višeslojnom kompjutoriziranom tomografijom u Županijskoj bolnici Livno. Zdravstveni glasnik. 2020;6(2):13-22.

da je statistički značajno veća prisutnost anksioznosti pacijenata prije pregleda, nego poslije pregleda. Muscarneri i sur. su 2014. godine proveli istraživanje koje se bavilo razinom anksioznosti u pacijenata kojima je ordiniran radiološki pregled (19). Za razliku od metodologije ovog rada, Muscarneri i sur. su se orijentirali na onkološke bolesnike, naročito one kojima je ordinirana mamografija. Nadalje, Muscarneri i sur. su uključili veći broj ispitanika u odnosu na ovo istraživanje, njih 172 od kojih je najveći broj podvrgnut CT pregledu. Autori navedenog rada su koristili iste mjerne instrumente za mjerenje razine anksioznosti poput autora ovog rada. Rezultati Muscarneria i sur. pokazuju da je u $69 \%$ ispitanika pronađena visoka razina anksioznosti. Za razliku od našeg istraživanja, u metodologiji rada Muscarneria i sur. nije rađena podjela anksioznosti na anksioznost stanja i ličnosti. Njihovi rezultati pokazuju da je najviša razina anksioznosti pronađena $\mathrm{u}$ ispitanika kojima je ordiniran MRI pregled.

Rezultati ove studije pokazuju da razina obrazovanja utječe na višu razinu anksioznosti u obadvije skupine pacijenata. Ovi rezultati se podudaraju s rezultatima istraživanja koje su proveli Yu i sur. 2011. godine koje se bavilo proučavanjem razine anksioznosti u onkoloških pacijenata prilikom iščekivanja dijagnostičkog radiološkog pregleda (20). Njihovi rezultati također pokazuju da je razina obrazovanja povezana s razinom anksioznosti. Yu i sur. su koristili istu vrstu upitnika za ispitivanje anksioznosti. Njihovi rezultati pokazuju da spol i dob ispitanika utječu na razinu anksioznosti. Rezultati ove studije pokazuju da dob i spol ispitanika ne utječe statistički značajno na razinu anksioznosti u istraživanom uzorku. U svijetu su provedena brojna istraživanja koja su se bavila razinom anksioznosti prilikom iščekivanja raznih vrsta radioloških pretraga. Bölükbaş i sur. su proveli istraživanje koje se bavilo ispitivanjem razine anksioznosti u žena kojima je ordiniran pregled mamografijom (21). Njihovi rezultati pokazuju da su ispitanice nakon pregleda mamografijom imale prosječnu razinu anksioznosti. Rezultati navedenog istraživanja poput ovog istraživanja pokazuju da razina obrazovanja značajno utječe na razlike između skupina u odnosu na razinu anksio- znosti. Prema istraživanju koje je provedeno u Švedskoj 2006. godine, dvogrupni kontrolirani eksperimentalni dizajn korišten je kod pacijenata kojima je planiran MRI pregled, a podijeljeni su u kontrolnu i interventnu skupinu (22). Ukupno je ispitano 390 pacijenata, od čega ih je 193 pripadalo kontrolnoj skupini, a 197 interventnoj skupini. Nije bilo značajnih razlika između kontrolnih i interventnih skupina u vezi anksioznosti prije ili tijekom skeniranja. Rezultati navedenog istraživanja se razlikuju od rezultata ovog rada u kojem je zabilježena značajna razlika u anksioznosti stanja između skupina. Klaming i sur. 2015. godine su proveli istraživanje o utjecaju anksioznosti na pomake pacijenta tijekom MRI pregleda (23). Premda se u literaturi često navodi da visoka razina anksioznosti može utjecati na pomicanje pacijenta tijekom pregleda, rezultati Klaminga i sur. pokazuju da nisu pronađeni dokazi koji statistički značajno upućuju na povezanost anksioznosti i pomicanja pacijenata tijekom MRI pregleda. Heyer i sur. u radu objavljenom 2015. godine navode da anksioznost nije samo prisutna prije i tijekom MRI pregleda, nego i kod CT pregleda (24). U ovom radu analizirani su razni parametri poput dijagnoze, dužine trajanja pretrage, davanje kontrastnog sredstva te klaustrofobija. Za razliku od rezultata ovog rada koji pokazuju da nema značajne razlike u razini anksioznosti prema spolu, rezultati Heyera i sur. pokazuju da su žene anksioznije od muškaraca. Rezultati Yıldızera u istraživanju provedenom 2017. godine pokazuju da se ne može do kraja sa sigurnošću utvrditi povezanost anksioznosti s pomicanjem pacijenta tijekom CT pregleda, no da je zabilježena viša razina anksioznosti u osoba u kojih su detektirani pomaci pacijenta prilikom pregleda (25).

Morel i sur. proveli su istraživanje o utjecaju MRI uređaja prilagođenog djeci na smanjenje anksioznosti kod djece i njihovih roditelja (26). Rezultati njihovog istraživanja pokazuju da takvi MRI uređaji utječu na manju razinu anksioznosti kod djece. Jaite i sur. navode da rezultati njihove komparativne studije ne pokazuju značajnu razliku između anksioznosti kod djece i adolescenata kojima je ordiniran MRI pregled od onih koji su podvrgnuti elektroencefalografiji (27). 
Badrov S, Babić D, Franjić D, Martinac M, Miljko M. Anksioznost pacijenata kod pregleda višeslojnom kompjutoriziranom tomografijom u Županijskoj bolnici Livno. Zdravstveni glasnik. 2020;6(2):13-22.

Ohana i sur. su 2019. godine proveli istraživanje o prisutnosti anksioznosti kod pregleda CT angiografijom koronarnih arterija (28). Rezultati njihove studije pokazuju da je anksioznost zabilježena kod $74,1 \%$ ispitanika, što označava visoku razinu anksioznosti. Ohana i sur. navode da anksioznost u njihovom radu nije utjecala na kvalitetu i interpretaciju slika. Uzorak u njihovoj studiji predstavljala su 344 pacijenta, što je dosta više nego u ovoj studiji. Ohana i sur. su koristili drugu vrstu upitnika za analizu anksioznosti, revidiranu skalu utjecaja traumatskog događaja (IES-6). Lambertova i sur. su 2019. godine proveli istraživanje o svjesnosti pacijenata u odnosu na rizik i moguće komplikacije tijekom kontrastnog CT pregleda (29). Njihovi rezultati pokazuju da većina ispitanika nije upoznato s mogućim komplikacijama uzrokovanih kontrastom te da bi informacije o komplikacijama i rizicima tijekom kontrastnog CT pregleda povećale strah i anksioznost kod pacijenata. U ovoj studiji nije provedena analiza znanja ispitanika o MSCT pretrazi, što bi dobro bilo ispitati u budućim istraživanjima na ovu temu. Li i sur. su proveli istraživanje koje se bavilo utjecajem anksioznosti na uspješnost CT koronarne angiografije (30). Rezultati njihove studije pokazuju da anksioznost može predstavljati značajan nedostatak i prepreku prilikom izvođenja pregleda CT koronarnom angiografijom. Li i sur. su za analizu razine anksioznosti poput autora ovog rada koristili skalu za samoprocjenu anksioznosti.

$\mathrm{Na}$ našim prostorima je provedeno nekoliko istraživanja koja su se bavila anksioznošću u raznim populacijama kod radioloških pregleda, prilikom različitih vrsta liječenja u onkoloških bolesnika, različitih vrsta oboljenja i u raznim situacijama. Tako su Ljubić i Babić 2017. godine proveli istraživanje koje se bavilo anksioznošću studenata Fakulteta zdravstvenih studija u Mostaru prije i nakon ispita (31). Autori zaključuju da statistički značajno veća anksioznost postoji kod studenata prije ispita nego poslije ispita. Nadalje, zaključuju da se razina anksioznosti kao stanja ličnosti u ispitanika pokazala se statistički značajno veća u odnosu na anksioznost kao osobine ličnosti. U navedenom obilježju njihovi rezultati se podudaraju s rezultatima ovog rada. Lju- bić i Babić su koristili istu vrstu upitnika za analizu razine anksioznosti kao autori ovog rada. Bagarić i sur. u svom istraživanju na temu anksioznosti u pacijenata kojima je ordinirana pretraga MRI-om iz 2018. godine navode da je testiranjem utvrđeno da su ambulantni ispitanici pokazivali u značajno višem omjeru blagu, umjerenu i tešku depresivnost u odnosu na bolničke pacijente (32). Ambulantni bolesnici su značajno duže čekali na pregled, te su imali značajno viši stupanj anksioznosti i depresivnosti. U navedenoj studiji korišteni su drugačiji instrumenti za prikupljanje podataka o razini anksioznosti u odnosu na ovaj rad. Bagarić i sur. su koristili Beckov upitnik za anksioznost. Bagarić i sur. su pored anksioznosti ispitivali i razinu depresivnosti u istraživačkoj populaciji. Hrkać i sur. su 2019. godine objavili rad koji se bavio anksioznošću u onkoloških bolesnika liječenih kemoterapijom i zračenjem. Zaključuju da su ispitanici u skupini s kemoterapijom postizali statistički značajno više rezultate na skali anksioznosti (33). Šehanović i sur. u istraživanju objavljenom 2020. godine navode da su svi ispitanici oboljeli od Parkinsonove bolesti i multiple skleroze iskazivali određeni stupanj anksioznosti (34). Babić i sur. u knjizi objavljenoj 2020. godine navode istraživanje u kojem je kod 25-37 \% bolesnika, koji su imali iskustvo snimanja MSCT-om, zabilježena umjerena do visoka razina anksioznosti, te ih je 1,5-6,5 \% prekinulo pretragu (12). Za razliku od rezultata ovog rada u kojima je zabilježena razlika između anksioznosti prije i poslije pretrage, Babić i sur. navode da nije bilo značajnih razlika između kontrolnih i interventnih skupina u vezi anksioznosti prije ili tijekom skeniranja.

Iz dosadašnje literature vidljivo je da se studije uglavnom razlikuju u metodologiji istraživanja. Najčešće razlike su u primjeni mjernih instrumenata, odabiru kontrolnih skupina te broju ispitanika i uključenih radioloških pretraga $\mathrm{u}$ analizu. $\mathrm{U}$ svrhu dobivanja pouzdanijih rezultata o anksioznosti pacijenata kod MSCT pregleda i detektiranja čimbenika koji utječu na pojavnost anksioznosti u pacijenata, u daljnjim istraživanjima potrebno je analizirati svjesnost pacijenata o mogućim komplikacijama koje se mogu dogoditi tijekom MSCT pregleda, po- 
Badrov S, Babić D, Franjić D, Martinac M, Miljko M. Anksioznost pacijenata kod pregleda višeslojnom kompjutoriziranom tomografijom u Županijskoj bolnici Livno. Zdravstveni glasnik. 2020;6(2):13-22.

najviše u odnosu na pojavu alergijskih reakcija pri apliciranju kontrastnog sredstva. Kao nadopuna rezultatima dobivenih $\mathrm{u}$ ovom istraživanju, $\mathrm{u}$ daljnjim istraživanjima potrebno je analizirati povezanost anksioznosti s pomicanjem pacijenata tijekom MSCT pregleda.

\section{ZAKLJUČCI}

Statistički značajno veća je prisutnost anksioznosti pacijenata prije pregleda, nego poslije pregleda MSCT-om. Razina anksioznosti kao stanja ličnosti u ispitanika je statistički značajno manja u odnosu na anksioznost kao osobine ličnosti. Nije bilo statistički značajnih razlika u rezultatima na testovima anksioznosti među spolovima. Stručna sprema, zaposlenost i religioznost nisu pokazali statistički značajnu povezanost s razinom anksioznosti kao stanjem pri pregledima. Ispitanici s nižom stručnom spremom su postigli statistički značajno najviše rezultate na upitniku kojim se procjenjivala anksioznost kao osobina ličnosti. Ispitanici koji su se izjasnili da ne piju alkoholna pića statistički značajno imaju višu razinu anksioznosti kao osobinu ličnosti od ostalih ispitanika.

\section{LITERATURA}

1. Vlašić D. Anksioznost pacijenata vezana uz radiološke postupke. Zagreb: Zdravstveno veleučilište; 2017 [pristupljeno 30.10.2020.]. Dostupno na: https://urn.nsk.hr/urn:nbn:hr:139:554775

2. Gregurek R, Braš M. Psihoterapija anksioznih poremećaja. Medix. 2007;71:72-74.

3. Zaharija I. Simptomi anksioznosti. Pliva zdravlje [Internet]. 2020 [pristupljeno 30.10.2020.]. Dostupno na: https://www.plivazdravlje.hr/aktualno/clanak/33656/Simptomi-anksioznosti. html

4. Tornquist E, Mansson A, Larsson EM, Hallstrom I. Its like being in another world-patients lived expirience of magnetic resonance imaging. Journal of Clinical Nursing. 2006a;15:954-61.

5. Lo Re G, De Luca R, Muscarneri F, Dorangricchia P, Picone D, Vernuccio F, et al. Relationship between anxiety level and radiological investigation. Comparison among different diagnostic imaging exams in a prospective single-center study. Radiol Med. 2016 Oct;121(10):763-8.

6. Semnic R. CT toraksa i abdomena. 1. izd. Novi Sad: Institut za Onkologiju, Sremska Kamenica; 2005.

7. Mcrobbie DW, Moore EA, Graves MJ, Prince MR, MRI from picture to proton, 2 md edn. Cambridge: Cambridge University Press; 2007.

8. Gorman JM. Comoebid depression and anxiety spectrum disorders. Depress Anxiety. 1996;4:16-8.

9. Quirk ME, Letendre AJ, Ciottone RA, Lingley JF. Anxiety in patients undergoing MR imaging. Radiology. 1989;170:463-6.

10. Dražen B. Psihopatologija. Drugo dopunjeno i obnovljeno izdanje. Zagreb: Medicinska naklada; 2014.

11. Shafran R, Mansell W. Perfectionism and psychopathology: a review of research and treatment. Clinic Psychol Rev. 2001;21:879-906.

12. Babić D. i sur. Psihologija u medicini i zdravstvu. Prvo izdanje. Mostar: Sveučilište u Mostaru; 2020.

13. Syncamore JE, Corey AL. Reducing test anxiety. Element School Guid \& Counsel. 1990;24:2313.

14. Horvat M. Evaluacija Upitnika anksioznosti kao stanja i osobine STAI (Diplomski rad). Odsjek za psihologiju Filozofskog fakulteta, Sveučilišta u Zagrebu; 2002.

15. Breuer K. Chronic stress experience and burnout syndrome have appreciable influence on health-related quality of life in patients with psoriasis. Jeady. 2015;29:1898-1904.

16. Burgstahler C, Schroeder S. Magnetic resonance imaging versus computed tomography for the detection of coronary stenosis: do we really have to focus on "stenoses"? Heart. 2007 Nov;93(11):1322-4.

17. Lo Re G, De Luca R, Muscarneri F, Dorangricchia P, Picone D, Vernuccio F, et al. Relationship between anxiety level and radiological investigation. Comparison among different diagnostic imaging exams in a prospective single-center study. Radiol Med. 2016 Oct;121(10):763-8. 
Badrov S, Babić D, Franjić D, Martinac M, Miljko M. Anksioznost pacijenata kod pregleda višeslojnom kompjutoriziranom tomografijom u Županijskoj bolnici Livno. Zdravstveni glasnik. 2020;6(2):13-22.

18. Flory N, Lang EV. Distress in the radiology waiting room. Radiology. 2011 Jul;260(1):166-73.

19. Muscarneri F, De Luca R, Lo Re G, Cicero G, Scopelliti L, Maniaci G. Evaluation of anxiety level in patients wating to undergo to diagnostic radiological exams. Conference: European Society of Radiology. 2014;1-4.

20. Yu LS, Chojniak R, Borba MA, Girão DS, Lourenço MT. Prevalence of anxiety in patients awaiting diagnostic procedures in an oncology center in Brazil. Psychooncology. 2011 Nov;20(11):1242-5.

21. Bölükbaş N, Erbil N, Kahraman AN. Determination of the anxiety level of women who present for mammography. Asian Pac J Cancer Prev. 2010;11(2):495-8.

22. Ahlander BM, Arestedt K, Engvall J, Maret E, Ericsson E. Development and validation of a questionnaire evaluating patient anxiety during Magnetic Resonance Imaging: the Magnetic Resonance Imaging-Anxiety Questionnaire (MRIAQ). J Adv Nurs. 2016;72:1368-80.

23. Klaming L, van Minde D, Weda $H$, Nielsen $T$, Duijm LE. The relation between anticipatory anxiety and movement during an MR examination. Acad Radiol. 2015 Dec;22(12):1571-8.

24. Heyer CM, Thüring J, Lemburg SP, Kreddig N, Hasenbring M, Dohna M, Nicolas V. Anxiety of patients undergoing CT imaging-an underestimated problem? Acad Radiol. 2015 Jan;22(1):105-12.

25. Yıldızer Keriş E. Effect of patient anxiety on image motion artefacts in CBCT. BMC Oral Health. 2017 Apr 4;17(1):73.

26. Morel B, Andersson F, Samalbide M, Binninger G, Carpentier E, Sirinelli D, Cottier JP. Impact on child and parent anxiety level of a teddy bear-scale mock magnetic resonance scanner. Pediatr Radiol. 2020 Jan;50(1):116-120.

27. Jaite C, Kappel V, Napp A, Sommer M, Diederichs $\mathrm{G}$, Weschke B, et al. A comparison study of anxiety in children undergoing brain MRI vs adults undergoing brain MRI vs children undergoing an electroencephalogram. PLoS One. 2019 Mar 7;14(3):e0211552.
28. Ohana M, Sellers SL, Mooney J, Kueh SH, Grover $\mathrm{R}$, Arepalli CD, et al. Prevalence and impact of scan-related anxiety during coronary CT angiography: A prospective cohort study of 366 patients. J Cardiovasc Comput Tomogr. 2018 Sep-Oct;12(5):364-371.

29. Lambertova A, Harsa P, Lambert L, Kuchynka P, Briza J, Burgetova A. Patient awareness, perception and attitude to contrast-enhanced CT examination: Implications for communication and compliance with patients' preferences. Adv Clin Exp Med. 2019 Jul;28(7):923-929.

30. Li H, Jin D, Qiao F, Chen J, Gong J. Relationship between the Self-Rating Anxiety Scale score and the success rate of 64-slice computed tomography coronary angiography. Int J Psychiatry Med. 2016;51(1):47-55.

31. Ljubić O, Babić D. Anksioznost studenata Fakulteta zdravstvenih studija u Mostaru prije i nakon ispita. Zdravstveni glasnik [Internet]. 2017 [pristupljeno 2.11.2020];1:36-44. Dostupno na: https://fzs.sum.ba/sites/default/files/ Glasnik\%205.pdf

32. Bagarić M, Babić D, Pavlović M. Anksioznost i depresivnost pacijenata kojima je ordinirana pretraga magnetnom rezonancom. Zdravstveni glasnik [Internet]. 2018 [pristupljeno 31.10.2020];1:33-39. Dostupno na https://fzs. sum.ba/sites/default/files/Glasnik\%207.pdf

33. Hrkać I, Pavlović M, Haxhibeqiri S, Babić R, Martinac M, Babić D. Usporedba anksioznosti i depresivnosti u onkoloških pacijenata liječenih kemoterapijom i zračenjem. Zdravstveni glasnik [Internet]. 2019 [pristupljeno 01.11.2020.];5(1):40-47. Dostupno na: https:// hrcak.srce.hr/227717

34. Šehanović A, Tupković E. Komorbiditet depresije i anksioznosti kao odrednice kvalitete života u oboljelih od Parkinsonove bolesti i multiple skleroze. Zdravstveni glasnik [Internet]. 2020 [pristupljeno 01.11.2020.];6(1):90-94. Dostupno na: https://hrcak.srce.hr/239150 


\title{
ANXIETY OF PATIENTS UNDERGOING MULTISLICE COMPUTED TOMOGRAPHY AT THE COUNTY HOSPITAL IN LIVNO
}

\author{
Stipe Badrov ${ }^{1}$, Dragan Babić, ${ }^{1,2}$, Darjan Franjić, 1,3 , Marko Martinac ${ }^{2}$, Miro Miljko \\ ${ }^{1}$ Faculty of Health Studies University of Mostar \\ ${ }^{2}$ Clinic for Psychiatry University Clinical Hospital Mostar \\ ${ }^{3}$ Clinic for Oncology University Clinical Hospital Mostar \\ 88000 Mostar, Bosnia and Herzegovina
}

\begin{abstract}
INTRODUCTION: Multislice Computed Tomography (MSCT) is painless, but can be stressful for patients and cause anxiety.

OBJECTIVE: Determine the incidence of anxiety in patients before and after examination of multislice computed tomography.

METHODS: The study included patients undergoing an MSCT examination at the County Hospital in Livno. The test group $(\mathrm{N}=50)$ consisted of subjects undergoing an MSCT examination. The control group $(\mathrm{N}=50)$ consisted of subjects undergoing an X-ray examination. We used a Sociodemographic variables questionnaire and The State-Trait Anxiety Inventory (STAI).

RESULTS: The level of anxiety as a personality state was statistically higher in the control group. In relation to anxiety as a personality trait in the study group, there were no statistically significant differences in the results between the groups. Subjects with a lower educational attainment and those who do not consume alcohol achieved statistically higher results on The State Anxiety Inventory.
\end{abstract}

CONCLUSION: The level of anxiety was statistically higher before than after examination. The level of anxiety as a personality state proved to be statistically lower when compared to anxiety as a personality trait.

Key words: anxiety, patients, examination, multislice computed tomography

Correspondence:

Professor Dragan Babić, MD, PhD

E-mail: dragan.babic@fzs.sum.ba 